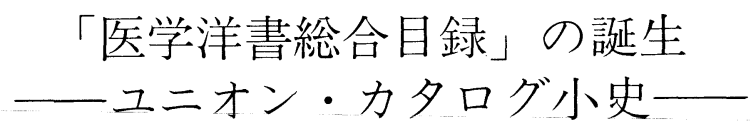

\title{
Birth of the "Union Catalog of Foreign Medical Books" - Short History of the Union Catalog
}

（1）第 10 回総会（昭和 11 年）～第 20 回総会（昭和 24 年） —「インフォメーション・ビューロー」と「Union Catalogue

堀 江 幸 司 山根京* 東京女子医科大学図書館

Horie, K., Yamane, K. : Birth of the "Union Catalog of Foreign Medical Books" - Short History of the Union Catalog-. Igaku Toshokan 30 (4) : 342-351, 1983.

The Japan Medical Library Association was established in 1927, and its major role is interlibrary loan activities. Arranging the "Union Catalog" of journals and books (holdings list), which is based on the interlibrary loan activities, is one of the basic tasks of the Association. As for the "Union Catalog" of foreign medical books, a total of eight volumes of the "Union Catalogue of Foreign Books in the Libraries of Japanese Medical Schools" were published from 1949 to 1956. This so-called "Union Catalog" has been edited by using a computer from 1977 up to the present. This study reports the history of the "Union Catalog."

\section{I.はじめに}

昭和 57 年 3 月, 「医学洋書総合目録, 1980」(図 1) が発行された。この編集担当館が東京女子医科大学図 書館 (以下当館という) であったわけだが，昭和 55 年 の月刊版の編集に始まって累積版の作成まで，まさに 「ユニオン・カタログ」に忙殺された 2 カ年であった。 システム設計，館内·館外の担当分担·調整，マニュ アルの作成，基本的資料の調查・整備等々，解決し即 実行に移さなければならない問題が山積みであった。

このような状況のなかで，ワーク・シートを作成し， あるいはゲラ刷りを校正しながらいつも思い浮かべた のは,「医学洋書総合目録」の前身である「Union Catalogue of Foreign Books in the Libraries of Japanese Medical Schools」(図 2 ) (以下「Union Catalogue」 という）の序文にある次の一節であった。

r......これは近代日本医学界最大の文献書目であり, この種のものとしては世界でも希有なことで昭和十七

* Koji HORIE, Kyo YAMANE : Tokyo Women's Medical College Library, 10 Kawada-cho, Ichigaya, Shinjuku-ku, Tokyo 162, Japan.

(昭和 58 年 11 月 10 日 受理)
年刊行した医科大学々術雑誌目録と共に, 医学文化史 上の重要な史料となろう。…...

この一節には, 日本医学図書館協会（当時，医科大 学附属図書館協議会）を築いてきた人々の「Union Catalogue」に対する情熱と嗼りが感じられるのである。

本稿では，この「医学洋書総合目録」誕生までの，い わゆる「ユニオン・カタログ」の歴史を概観する。

II. 第 10 回総会(昭和 11 年) 〜第 20 回総会(昭和 24 年)——インフォメーション・ビュー ロー」と「Union Catalogue $\lrcorner-$

「ユニオン・カタログ」の歴史は, 今から 47 年前の 昭和 11 年にまでさかのぼる。

昭和 11 年 5 月 27 日 29 日の 3 日間, 熊本医科大学 で開催された第 10 回医科大学附属図書館協議会の席 上, 岡山(遠藤竹秋) から協議題として,「協議会として 共同図書目録編纂の件」が提出された。これが,「ユ二 オン・カタログ」のはじまりである。この第 10 回総会 では，後年「ユニオン・カタログ」で中心的役割を担 うことになる慶応と東大が協議会からの针誘に応じて 加盟している。慶応からは草間良男館長が, 東大から 
堀江・山根：「医学洋書総合目録」の誕生一ユニオン・カタログ小史一(1) 343

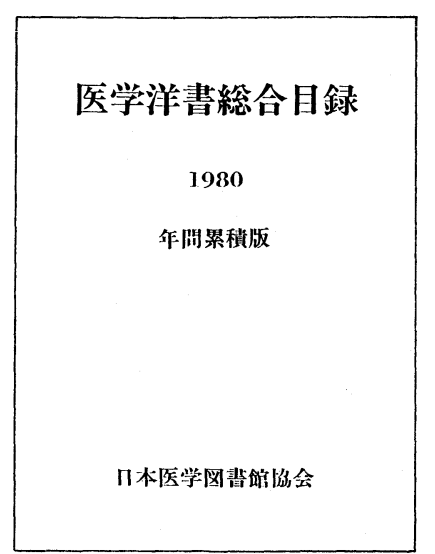

図 1.「医学洋書総合目録, 1980」

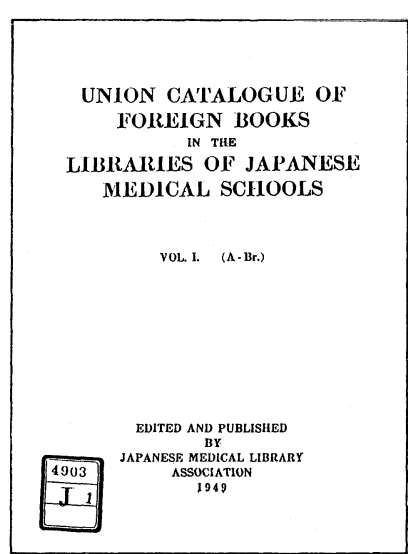

図 2. 「Union Catalogue of Foreign Books in the Libraries of Japanese Medical Schools」
は木村重三郎が出席した。

遠藤竹秋の提案理由は,「雑誌にありては，共同雑誌 目録編纂せられ相互貸借の途講ぜられ居るも, 単行書 にありましては，未だ其時期に達せず，速かに共同困 書目録の編纂されん事を希望す」というものであった。 審議の中で,さらに遠藤竹秋は,「理由書に書いて居り ます通り，単行本も雑誌同様に相互貸借が出来ればと 思U, 就ては共同雑誌目録に対し共同図書目録が出来 なければならないと思Uます, 之が出来れば閲覧上並 経済上甚だ便利であると思ひます」と述べている。こ れに対して, 名大(清川陸男) は「其の第一着として慶 応, 大阪のやうに各大学の単行本の目録を作って交換 して頂きたいと存じます」と述べたが, 新潟 (渡邊正亥) は、「目録交換が出来ないからこの種の問題を出された と思ひます。此の問題の難点は第一に分類であり, 第 二に経費のことだと存じますが，先ず手始めに『イン フォメーション・ビューロー』を作り，其處に一枚な り二枚なりの『カード』を送って集めて置きます。そ して借りたい大学からその本の有無を『ビューロ一』 に間合はせるということにすると大変都合がいいと思 ひます。」と述べている。

この「インフォメーション・ビューロー」の提唱者 であった渡邊正亥は，後に(昭和 22 年)「Union Catalogue」(欧文の「医科大学綜合医書目録」) の専任者と なり, 新潟県立図書館長を経て, 昭和 38 年 4 月〜 40 年 8 月には順天堂大学の図書館長を務めた。現在順天が 「医学洋書総合目録」(1981，1982，1983）の担当館と して，その編集の中心的役割を担っていることを考え
ると興味深い。

この「インフォメーション・ビューロー」の構想が 後年 (昭和 39 年) の慶応における「医学文献センタ一」 へとつながることになる。

協議題は，宿題として翌年に持ち越された。

第 11 回総会(新潟) (昭和 12 年)には, 前回の総会で 「共同図書目録の編纂」を提唱した岡山の遠藤竹秋は 欠席であった。そして, 同じく岡山の緒方益雄館長か ら「……本案は大事業たるのみならず本館に於いても 目下蔵書整理中にして今遽かに云々すべき事に非ざれ ば本案を一応撤回致したし」との申し出があり, 了承 された。

新たに名大(清川陸男)が, 協議題として「本会内に インフォメーション・ビューロー(Information Bureau）の如きものを設け加入館に於ける新購入図書を, 何等かの形式にて月一回同局に送付報告するの件」を 提出した。

この提案理由は,「本会綜合困書目録編纂並に単行書 相互貸借準備事業の第一歩として最新購入 (昭和 12 年 度)の分より之を実行, 従前蔵書の分に対しては或る一 定の協定期間中に各館蔵書名を報告することとせば綜 合目録編纂の下準備となる。加之目録上梓前既に希望 困書の有無は同局に照会することに依り容易に知り得 ることを得。本会事業の一つとして研究に裨益する廉 不尠と認む」というものであった。

清川陸男は前回の総会では，各大学で作成した冊子 体目録を交換すれば，当面は「共同図書目録」を編纂 
する必要はないとの立場をとった。しかし，本総会で は，遠藤竹秋，渡邊正亥の意見を入れて,「医科大学附 属図書館協議会」の事業として「ユニオン・カタログ」 を位置づけ，その基本構想をまとめあげたのである。

審議の結果，綜合目録編集・単行図書相互貸借準備 として, 名大に「インフォメーション・ビューロー」 が設置されることになった。

「インフォメーション・ビューロー」の提唱者は, 新潟の渡邊正亥, 実現者は名大の清川陸男であったと いえる。清川陸男は, 後に群馬の梅枝軍二(現当館)の 推薦によって名誉顧問となった金沢の三宅次吉による と,「官立医科大学附属図書館協議会」の「産婆役」と して活躍した協議会創立の中心人物の一人であった。 第 1 回総会当時 (昭和 2 年) 清川陸男は新潟で渡邊正亥 と共に宮路重嗣館長の下にいたが，昭和 6 年，林亥之 助教授の招きで新潟を退官し，名大へ移っていたので ある。

なお，この第 11 回総会には，戦後「Union Catalogue」の編纂に情熱を傾けた中山勇之助 (新潟)が当番 館の一員として参加している。

第 12 回総会(岡山) (昭和 13 年)において, 阪大(藤 木好三郎)から，協議題として「インフォメーション・ ビューローへの報告に，ある制限を附しては如何」が 提出された。

この提案理由は,「普通の図書は何處にもあり故に之 を省略して次のものに限定しては如何。A，特殊なる ものB. 金額例之ば百円以上のもの」というものであっ た。この藤木好三郎の提案は, 現在も問題となってい る「収録範囲」を報告カード提出の簡略化の観点から, 明確にしようとするものであった。藤木好三郎は次の ように説明している。「新購入図書のインフォメーショ ン・ビューローへの報告内容が余り複雑にきめられて あるから，なかなか面倒なので何處にも備付られてあ る普通書をビューローへの報告より省き, 報告を提案 の範囲に制限しては如何と云うにあり」。

この提案に対して「インフォメーション・ビュー ロー」の設置館であった名大(清川陸男)は,「普通書の 報告を省くと云ふことは,『ビューロー』の機能上甚だ 面白から妨とと思ひます」と，即座に反対した。ま た，渡邊正亥からは，「我々は所要の単行書が何處にあ るかを知りたい。従って簡単でも凡ての図書を全部イ ンフォメーション・ビューローに報告することがよい
と思ひます。尚ビューローへの報告は簡単な報告をな すことで満足したい」との意見が出された。東北(吉岡 孝治郎)からは「インフォメーション・ビューローに全 医大の資料が集まるから年報, 又は報告を出して載け れば非常に結構ですが」との発言があった。

審議の結果, 「インフォメーション・ビューロー」へ の報告は各大学が原則的に毎月一回報告することと し「ビューロー」からは年 4 回報告書を発行すること」 が決議された。しかし，この年 4 回の報告はその後一 度も発行されなかったようである。

第 13 回総会(慶応) (昭和 14 年)において, 岡山（遠 藤竹秋) から協議題として,「現在名古屋帝国大学附属 図書館内に設置してあるインフォメーション・ビュー ロー強化に就て」が提出された。

この提案理由は,「外国為替管理の強化に伴いイン フォメーション・ビューローの利用が益々必要になっ てくる。各大学で協力の上一層その機能を発揮させる 様にしたい。一定の期限を附けて各館から全蔵書の目 録を名古屋へ報告することにしてはどゔかと思ふ」と いうものであった。

この提案に対して，名大(清川陸男)は「ビューロー への御報告が無い館もあり，一方館員の不足から前回 お引受した報告が出来なかった。各館の御援助を得て 折角努力したい」と述べた。

遠藤竹秋の提案は, 単行本相互貸借の重要性に立脚 したものではあったが, 名大一館の努力で, 全国加盟 館 (13 館)の昭和 12 年以前を含めた全蔵書をインフォ メーション用に整理しておくことは，現実的に不可能 なことであった。

審議の結果, 「インフォメーション・ビューローの強 化は結構なことであるが, 過去へ遡ることは各館共困 難の様であるから今後のものだけを報告すること」に 落ち着いた。

第 14 回総会(千葉) (昭和 15 年)において, 名大(清 川陸男)から協議題として,「インフォメーション・ ビューロ一其後の状況報告」が提出された。その中で, 「昭和 14 年度インフォメーション・ビューローへの報 告は, リストに依る報告 3 館, カード報告 4 館, 和書 2,662 冊, 洋書 1,334 冊, 利用申込は 1 回長崎よりあっ た」と報告されている。「インフォメーション・ビュー ロー」の利用は, 記録によればこの長崎が一番早かっ 
たことになる。この協議題とは別に, 同じく名大(清川 陸男) 加「医科大学附属図書館図書目録委員会設置の 件」が提出された。

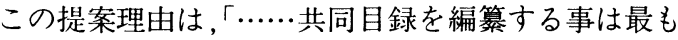
大切な事であるから，『インフォメーション・ビュー ロー』としては一定の『カタログ・ルール』を作って やって行きたい。それには是非委員会の設置が必要で ある。……というものであった。現在の Working Groupの前身であったといえる。

審議の結果, 名大(清川陸男), 新潟 (渡邊正亥), 千 葉(北村清)の 3 館によって準備委員会が設置されるこ とになった。

第 15 回総会(東大）(昭和 18 年)は,「ユニオン・カ タログ」にとって歴史的な総会であった。

慶応 (草間良男館長, 高木武之助)からは，協議題と して，「共同図書目録編纂の件」が提出され，一方，名 大(大島武四郎)からは「インフォメーション・ビュー ローに関する件」が提出された。この慶応が提案し た「共同図書目録」が，後年 (昭和 24 年 昭和 31 年) 「Union Catalogue」として結実するのである。
慶応の提案理由は,「戦時と外国書の入手不可能なる に伴ひ既存文献の徽底的利用を要請せられつつあり。 此の際速かに共同図書目録を編纂して図書相互貸借の 便に供するは刻下喫緊の要務なりと思考す」というも のであった。

この慶応の提案に対して, 岡山(関正次館長, 遠藤竹 秋)から具体的な作業方法が示された。それは，分野毎 に担当館を決定して，その分野の「コッピイリスト」 を作成し，これを各大学に配付し所蔵しているものに は○印を付け，他に所蔵しているものは書き加えて， 送り返してもらうという方法であった。(資料 1)

この計画は, 当番館の館長であった東大の太田正雄 教授(詩人, 劇作家 木下圭太郎)の「熱誠なる支持」 を得た。

その日(昭和 18 年 10 月 20 日)の午後一時から開催 された実務者編纂委員会 (全員) (京府・赤星軍次郎, 京城・津崎孝道, 新潟・渡邊正亥, 阪大・藤木好三郎, 金沢·三宅次吉，長崎・田鶴壽男，慶応・高木武之助, 千葉・北村 清, 名大 $\cdot$ 大島武四郎，岡山・遠藤竹秋, 東北・吉岡孝治郎，熊本・宮川喬次，東大·三輪福松）

(写真参照) によって，各大学の分担が決定された。

資料 1.「Union Catalogue」の発端となった昭和 18 年第 15 回総会の議事録

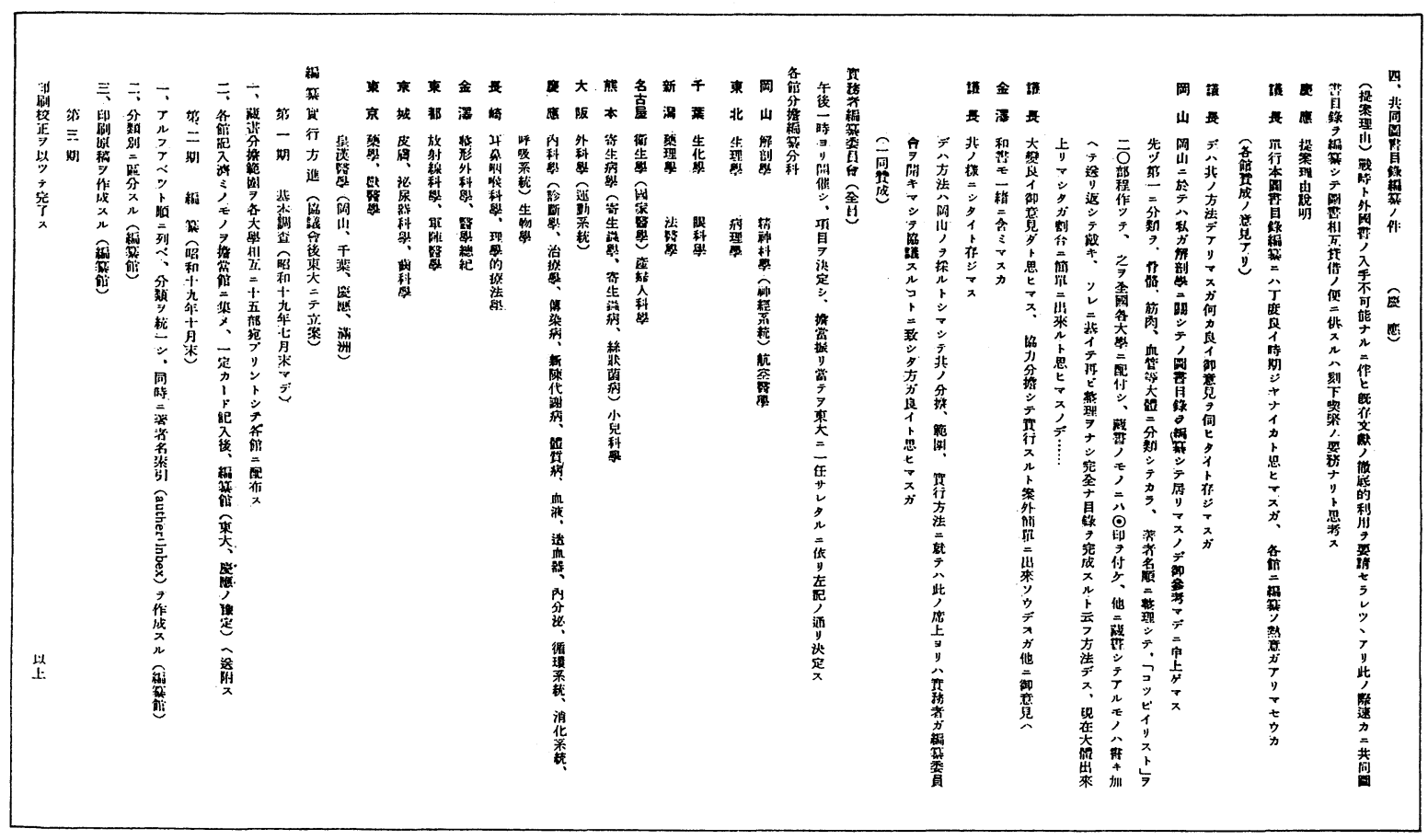


これに対して名大の提案理由は,「ビューロー事業経 過報告並今後該事業促進に関する提案」と題する, 議 事録 7 ページを割く長文のものであった。「インフォ メーション・ビューロー」への報告概数, 報告形式等 を詳しく報告した後, 以下の 3 点を提案している。

1.「第 14 回総会で決議されていた「医科大学附属困 書館図書目録委員会・準備委員会」を開催し，報 告すべき図書の範囲, 制限, 並単位報告カードの 規格及フォームの制定とふ, 該事業の中軸を為す 處の共同作業の組織，機構等の検討もすること」

2.「科学振興に関する国家的要望に応へ得る様な大 掛りで，インフォメーションを重点として医学共 同図書目録の刊行と米国議員図書館式印刷カード の頒布事業を兼行する施設。……之は無論医科大 学協議会の事業としてではなく, 今かりに文部省 科学課(局？)あたりに提議して容れられれば文部 省の事業としてでも鬼も角それに要する一切の経 費は文部省で賄ふて苜ふ，そして実際の事業は当 医科大学協議会の手でやること」

3.「敵性語排除現下の状勢に鑑み此の際インフォ メーション・ビューロー改図書通報局とか, 図 書資源通報部とすること」

ここで疑問となるのは，慶応の「共同図書目録」と 名大の「インフォメーション・ビューロー」の関係で ある。「インフォメーション・ビューロー」も「綜合四 書目録編纂の下準備」として設置されたものであるか ら,デー夕(報告カード)は十分に収集されていたはず である。しかし，議事録からは，この「報告カード」 が今回慶応から提案された「共同図書目録」に活用さ れていないように思われた。そこで, 中里龍瑛名誉顧 問にお目にかかってお伺いしてみた。それによると， 報告カードも「共同図書目録」に活用されたとのこと であった。

また, 渡邊正亥先生のお話によると, 岡山から提案 された「コッピイリスト」の案はぺーパープランに終 わったそうである。

「共同図書目録」は短期間のうちに冊子体目録として 作成することになり，また「インフォメーション・ ビューロー」はインフォメーション・サービス(所在問 合せ業務)をその機能として, 新しい情報を追加できる ということで，双方とも協議会の事業として継続され ることになったのである。

なお,名大の清川陸男は前回の第 14 回総会を最後に
四書館界から引退していたが,この第 15 回総会におい て, 協議会の創設当時からの永年の尽力に対して表彰 されることになった。

戦後第 1 回の総会は, 昭和 21 年 6 月 28 日(金) 29 日 (十)の 2 日間, 変則的に実務者(司書)だけで, 京府で行 われた。この第 16 回総会(京府)では, 東大(三輪福松. 中里龍瑛)に中央事務局を置くことが決定されている。

協議題として, 東大 (三輪福松.中里龍瑛), 東北 (吉 岡孝治郎)から「共同目録作業促進の件」が提出され, 以下のことが決議された。

i ）編集方法が各館区々になることを避けるために， 編集委員を設けて統一することとし，新潟〔中山 勇之助〕 ·金沢〔三宅次吉〕 - 東北〔吉岡孝治郎〕 が委員となること。

ii）出版に要する費用の計算並びに文部省に対する費 用の支出方の交涉を, 中央委員特に東大〔三輪福 松・中里龍瑛〕が担当すること。

iii）長崎の原稿が焼失したので，各館は更にこれを作 成して送ること。

(〔 Љ内筆者補記)

戦後 1 力年もたた間に実務者のみによる総会が開 催されたことには，実務者の協議会存続にかける並々 ならぬ情熱を感じとることができる。

第 17 回総会(金沢)（昭和 21 年 10 月 15 日(火) 16 日 (水)）において, 協議題として, 束大(三輪福松) からは 「共同図書目録追加編纂並其の技術上方法の件」が提 出され，また，中央事務局からは，「共同図書目録編纂 促進の件に付其の後の経過報告」が提出された。中央 事務局として，はじめて総会に提出された協議題はこ の「ユニオン・カタログ」に関するものであった。

この総会には, 文部省から当時科学教育調查課長で あった馬場重徳 (現図書館短期大学名誉教授)が出席し た。馬場重德の力添えで共同図書目録の刊行が学術研 究会議の内に設置された「科学文献調查特別委員会」 の事業の一部として採択され，その編纂か協議会に委 嘱されたのである。この時, 原稿作成費(調查費)とし て, 65,000 円が文部省から支出されている。学術研究 
会議から出席した福田信夫は，この「調査費」の使途 について、「人件費あるいは通信費等に自由に使ってか まわないが，共同図書目録は協議会に加盟していな かった京大，九大，北大の 3 館を含めたものにするよ うに」指示している。65,000 円のうち，12,500 円が中 央事務費とされ，3,500 円が各館に分配された。

馬場重徳は当時の様子を「医学図書館」の中で次の ように語っている。少し長いが引用してみる。

「昭和 22 年頃学術研究会議学術文献調査研究特別委 員会でお世話になって居た東大の土井司書官の御紹介 で東大の医学中央四書室の三輪福松と言う方が私を尋 ねて来られ，医学図書の綜合目録の草稿が完全に出来 上って居るが出版費がない。出版をどうかしてくれと 言う御話であった。この言葉をすっかり信用して出版 出来る様に努力して見通しが立った時に，未だ不完全 で記入の統一，編成の再検が必要だからその補助金を くれと三輪さんが又来られた。言葉のあやと言い乍ら 面白い人も居るものだと思って, 特別委員会に計り医 学部の福田先生に特に説明を願って, この編纂の事業 を特別委員会の事業にして頂いたのである。

図書館にはこう言う人も居るとは面白い所だと思っ たこと，日本の戦後残った貴重な文献を綜合目録に編 成し, 精神的に再分配して万人の活発な利用に供する ことは極度に大切なこ之で，その観念に於いて，乏し い子算の中から相当額がこれに提供されたのである。 この医学綜合目録が印刷されて世の中に出る様になっ たのは，多くの人の善意と熱意にささえられて数年後 からであった。この問題では吉岡さん, 中里さん, 中 山さん(新潟)の熱心な推進があった」1)。

なお，この第 17 回総会で, 新潟の渡邊正亥と慶応の 高木武之助の退職にあたって感謝状が送られることに なった。また，新潟からは赤崎兼義館長が出席した。

第 18 回総会 (東北) (昭和 22 年)において, 名大 $(大$ 島武四郎) から協議題として，「インフォメーション・ ビューローは現在自然消滅の形ですが, 今後如何に處 置しますか」が提出された。審議の結果, 第 15 回総会 での決定通り，「名大に迷惑をかけないように原稿を整 頓の上，昭和 21 年 4 月以降のものを報告する」ことが 決議された。昭和 21 年 4 月以降とされたのは,「Union Catalogue」が, 昭和 21 年 3 月末までのものを原稿と したためである。

また, 慶応(飯沼守磨)からは, 協議題として「共同
目録出版促進の件」が提出された。この協議題提出に は,「共同図書目録」の提唱者としての慶応の並々なら ぬ熱意が感じとれるのである。

この提案理由は,「共同図書目録の印刷原稿を整備す るなめに新潟の渡邊正亥を専任者とし，手当を月 5 千 円位とし, 各館から分担金として 1 ケ月 400 円集める」 というものであった。

審議の結果，1～2 の大学で校閲することは困難で あるとして，新潟を退職していた渡邊正亥に「Union Catalogue」(医科大学綜合医書目録)の編集を専任と して依頼することになり，また他方，文部省にも予算 方を懇請することになった。

なお, 岡山の遠藤竹秋は前回第 17 回総会を最後に退 職していたが,この第 18 回総会において同氏に感謝状 および記念品が贈呈されることになった。

またこの総会には九大から山川幸雄 (現名誉顧問) が初参加している。山川幸雄は当時の模様を次のよう に語っている。

$\ulcorner\cdots \cdots .$. 終戦後 2 年目のことであり, 物資, 食糧とも に弿そした時代であった。九州から東北までの出張に 食糧 (白米一升, 南爪, 馬鈴薯, 玉葱)持参であった。 ところで当番館 (吉岡事務主任, 小野寺氏)の方では出 席者のために特に白米一升を紙袋にいれて希望者にわ ける用意がされていたのである。そのきめ細かい配慮 に恐縮せざるを得なかった。九州のやみ米価より東北 のそれの方が安価であったからである」。22

このように, 昭和 22 年は, 名大の「インフォメーショ ン・ビューロー」が再開され，また「Union Catalogue の編集が動き出した意義深い年であったといえる。

第 19 回総会 (阪大) (昭和 23 年)において, 新潟 (中 山勇之助) から協議題として,「医科大学綜合目録印刷 促進の件」が提出された。馬場重徳の意向を聴取した 後, 以下のように決議された。

1. 協議会が適当なる業者を選び再交渉すること。

2.各館は確実なる部数を 11 月中に中央事務局に報 告すること。

3. 新潟, 東京, 慶応, 大阪を業者選定の委員とす ること。

4.成るべく年度末にかからぬ様にすること。

渡邊正亥, 中山勇之助, 吉岡孝治郎, 中里龍瑛らの 努力で昭和 23 年には原稿の整理を終之, 第 1 巻の印刷 準備に取りかかることになったのである。 
この第 19 回総会から慶応の佐野輝夫が登場してい る。

第 20 回総会（名大）（昭和 24 年)には, 「ユニオン・ カタログ」関係の協議題は提出されていない。これは, 学制改革に伴う協議会の存続問題に審議が集中したた めであった。従来，協議会に私立は慶応しか加盟して いなかったが，これを機会に私立も拒むことなく「協 議会加盟基準」に従って加盟を認めることになった。

「医科大学附属図書館協議会」は「日本医学図書館協 議会」として再出発することになったのである。

協議題としては提出されなかったが，中山勇之助は 「医科大学綜合医書目録について」以下のように報告 している。

1. 第 1 号が出来上った。定価 500 円(送料を含む)
当初の子定価格一册 450 円より高くなったが印 刷費の值上げ等に依りいたし方ない。

2 、完成を急ぐために 2 印刷所に依頼する件。 出来上る物に多少の不満はあるが予算等の関係 上今年度内に是非仕上げたいから 2 印刷所に依 頼する。

3. 第 3 号以下の定価が一冊約 600 円程度になる。 各館協力して広告を集める。 文部省に援助を依頼する。

$\ulcorner$ Union Catalogue」の第 1 卷が出版されたのを機会 に，これを継続して刊行する費用を確保するために， 当時の高瀬文部大臣に北村包彦教授，草間良男教授， 滝澤延次郎教授らの連名で建議書が提出されることに なった。(資料 2 )その結果, 加盟館の各館長を研究員 として申請し，科学研究費として出してもらうことに

資料 2. 高瀬文部大臣への建議書 (写)

\begin{tabular}{|c|c|c|c|c|c|c|c|c|c|c|c|c|c|c|c|c|c|c|c|c|c|}
\hline 會 & 幅 & 就 & 办 & $x$ & 声 & 我 & \pm & 他 & 卖 & な & 事 & $\bar{\Sigma}$ & $\vec{J}$ & 0 & が & 8 & 氏 & 年 & $\kappa$ & 黑 & \\
\hline 9 & の & $r$ & ') & 你 & 目 & か & $\bar{x}$ & $t$ & 実 & 1) & $\varepsilon$ & $\hat{E}$ & 致 & 准 & 邦 & * & 4 & $i$ & 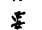 & $\vec{j}$ & \\
\hline 添 & 支 & は & ま & 者 & 隺 & 茄 & $t$ & 12 & 现 & $ま$ & な & 其 & $\hat{\imath}$ & 功 & 9 & 强 & は & $\tau$ & 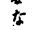 & $1=$ & (2) \\
\hline 羡 & 持 & $\dot{x}$ & $\frac{1}{9}$ & 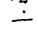 & 鼓 & 镐 & $k$ & 於 & の & L & ) & o. & 此 & $\frac{1}{k}$ & $E$ & 部 & 異 & 光 & J & 我 & \\
\hline 12 & 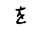 & 部 & & 同 & 褧 & 会 & 言 & $\tau$ & 地 & $r_{2}$ & 㫜 & 泼 & れ & 得 & 抙 & L & טי & 的 & 级 & ip & 医 \\
\hline 基 & 监 & 当 & & は & o & 6 & $B_{2}$ & 不 & 否 & 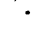 & 和 & 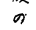 & 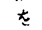 & $\tau$ & 四 & 尌 & 月 & 我 & $\frac{1}{2}$ & $g$ & 科 \\
\hline \pm & i & 司 & & 本 & 事 & $\theta$ & 第 & 成 & は & 吏 & 廿 & 拈 & 印 & 战 & $\overline{3}$ & 12 & $\div$ & क艹 & 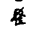 & 医 & 大 \\
\hline 芜 & 5 & $1=$ & & $=$ & 新 & 本 & $c$ & $\frac{1}{9}$ & 直 & 12 & - & 劦 & 剧 & 禹 & 寉 & 穒 & $\varepsilon$ & 邦 & 傮 & 堔。 & 堵 \\
\hline 12 & \& & 方三 & & $=$ & $0_{i}$ & 然 & + & 3 & 接 & 善 & 果 & $a$ & \#1 & 廿 & $1: \pm$ & 速 & $z$ & 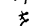 & 椋 & 文 & 零 \\
\hline 走 & $\angle$ & 办 & & $\pi$ & 成 & 特 & & 12 & 医 & 橴 & 四 & 好 & 行 & - & 2 & $\therefore$ & $=$ & 新 & R & 结 & 合 \\
\hline 禋 & 事 & 12 & & ע & 否 & 会 & & 日 & 䨜 & 9 & 月 & 等 & $i$ & 年 & 12 & $=$ & $\pi$ & れ & $\gamma$ & 9 & 远 \\
\hline 致 & $k$ & 2 & & $\pi$ & 心 & 鏐 & & 氷 & 研 & 潞 & 以 & 12 & 扊 & $=$ & 此 & $=$ & ン & $t=$ & 3 & 竞 & $\overline{7}$ \\
\hline L & 其 & は & & 7 & - & 9 & & 㜔 & 究 & 求 & 搂 & 依 & $<$ & 月 & 0 & 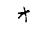 & 力 & 首 & $k$ & 狀 & 自 \\
\hline$\neq$ & $\hat{a}$ & 1 & & 口 & $1=$ & 右 & & 俈 & 活 & 设 & 0 & i) & ث & 现 & 器 & $=$ & 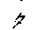 & 然 & 音 & 5 & 策 \\
\hline t & 䒠 & $\overline{=}$ & & ᄀ & 经 & 0 & & 会 & 站 & $\widehat{\text { 羍 }}$ & 医 & st & 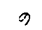 & 在 & E & t & a & 科 & 3 & 1) & 整 \\
\hline 1 & 施 & $\pi$ & & $\sigma$ & 裳 & 建 & & 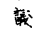 & 考 & 12 & 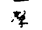 & 舟 & 利 & ז & 8 & $\phi$ & i & 狙 & 事 & $l$ & 偏 \\
\hline & 12 & ン & & 完 & $\theta$ & 被 & & は & 左 & 5 & 文 & $\Sigma$ & 翼 & 㙂 & 大 & 0 & 孝 & 新 & E & $\gamma$ & 侹 \\
\hline & 必 & 力 & & a & 3 & $1=$ & & 本 & 唐 & y & 列 & f & 12 & $?$ & $\theta$ & $\not$ & 始 & 成 & 㓞 & 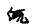 & 些 \\
\hline & 要 & $\not$ & & 9 & או' & 全 & & 思 & + & 新 & $B$ & 吾 & 供 & -7 & 类 & を & $n$ & 国 & $T$ & 存 & 方 \\
\hline & な & 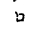 & & $\div$ & to & 面 & & 㳀白 & 3 & 㰸 & 就 & 科 & $-\frac{1}{4}$ & - & 心 & 敒 & $k$ & $\alpha$ & の & E & $k$ \\
\hline & 剔 & $\tau$ & & $\theta$ & 何 & 的 & & $a$ & $k$ & 医 & 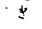 & $f$ & べ & 蕊 & を & 辞 & t & 文 & $*$ & 紫 & 敌 \\
\hline & 柾 & $a$ & & $t$ & 1? & $:=$ & & 裏 & 房 & 较 & 1 & 的 & 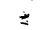 & $\bar{\Sigma}$ & 告 & 整 & 3 & 种 & 答 & 文 & + \\
\hline & 必 & 童 & & 早 & $n$, & 层 & & 要 & 3 & $\dot{x}$ & $=$ & sit & 设 & 管 & $\Perp$ & 傮 & 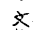 & 掌 & $\pi^{*}$ & 5 & 3 \\
\hline & 要 & 再 & & is & 、 & 意 & & 性 & ป & 拳 & $T$ & 然 & 覴 & 精 & $\sqrt{2 !}$ & + & 稪 & 敦 & か & 0 & 胥 \\
\hline & 貢 & 住 & & 事 & $\Rightarrow$ & l & & 12 & 遏 & os & $=$ & 梦 & 12 & 殸 & 萧 & る & 利 & 然 & 3 & $t$ & 部 \\
\hline & $\hat{n}$ & を & & है & $r$ & 得 & & 颌 & 吾 & 新 & $\Rightarrow$ & & 立 & 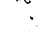 & $a$ & 事 & 用 & 里 & $r$ & 入 & $\underline{\xi}$ \\
\hline & 径 & 䜀 & & 念. & $E$ & 3 & & $2 x$ & で & $\begin{array}{l}\text { 设 } \\
\text { 都 }\end{array}$ & 5 & 交 & 些 & 医 & 齐 & $\Rightarrow$ & $i \dot{z}$ & ? & 不 & t & 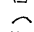 \\
\hline & 霓 & め) & & 䨳 & i) & $i$ & & 烽 & 厓 & $i=$ & 2 & 輨 & $\eta$ & 䒯 & 分 & 不 & 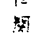 & 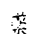 & l゙ & 利 & 萤 \\
\hline & i2 & 5 & & $\hat{l}$ & $\neq$ & ) & & 营 & l. & 伴 & 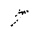 & $\therefore$ & $\div$ & 㘣 & 㞭 & मु & 䋛 & 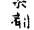 & \pm & 用 & \\
\hline & 就 & +2 & & 析 & i & ぐ & & a & 状 & is & $\Rightarrow$ & 茭 & L. & 专 & 3 & 篮 & d & 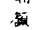 & t & 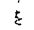 & \\
\hline & 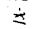 & 我 & & 角 & & あ & & 滛 & 㮣 & 京 & 纹 & is & $t_{2}$ & 12 & 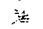 & な & 3 & $\mathrm{P}_{\mathrm{a}}^{\mathrm{T}} \mathrm{T}$ & & 討 & \\
\hline & 薏 & 驾。 & & 都闻 & & リ & & 伦 & $k$ & प & 噔 & 9 & & 础 & 层 & 3 & 菏 & 国 & & 3 & \\
\hline & 㘮 & 9 & & 製 & & ま & & 充 & な & 法 & 新 & 通 & & ง & $1=$ & $\bar{\square}$ & 宾 & 3 & & $r$ & \\
\hline & な & 計 & & 整 & & $l$ & & 慈 & i) & $\theta$ & 慜 & $i 2$ & & 3 & 就 & $\dot{q}$ & 革 & え゙ & & 共 & \\
\hline & 措 & 点 & & 偖 & & $\tau$ & & 理 & ま & 䌽 & 整 & $\hat{x}$ & & 總 & $\tau$ & 渱 & $a$ & 国 & & $r$ & \\
\hline & 宦 & $\overline{9}$ & & $l=$ & & 臬 & & 大 & $i$ & 急 & 倘 & 2 & & 合 & 特 & 胡 & 施 & 舍 & & 具 & \\
\hline & を & 实 & & 欮 & & $F$ & & 星 & $r_{2}$ & 尘 & $\theta$ & $z$ & & $\bar{E}$ & k & 暏 & 設 & 四 & & 9 & \\
\hline & 商 & 施 & & 力 & & 立 & & 及 & & क:" & 間 & 多 & & 素 & 研 & 示 & $?$ & E & & 利 & \\
\hline & ஷ゙ & 及 & & L & & $\overline{\text { 集 }}$ & & $u^{\prime \prime}$ & & 着 & 鬽 & 数 & & 百 & 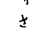 & \pm & 红 & $\stackrel{2}{2}$ & & 用 & \\
\hline & 5 & び & & 0 & & 実 & & 文 & & 3 & $D^{2}$ & $\lambda$ & & 像 & $\angle$ & 准 & 縺 & 数 & & 光 & \\
\hline & h & 全 & & $\checkmark$ & & 杝 & & 虾 & & $l$ & 聚 & 手 & & L & k & ま & 年 & 和 & & 证 & \\
\hline & 3 & 现 & & あ & & 中 & & 大 & & $<$ & 急 & i & & 9 & 裏 & $i$ & o & $\not$ & & 途 & \\
\hline & 些 & iz & & 3 & & $a$ & & 臣 & & 芝 & 9 & 得 & & 年 & $\sqrt{12}$ & I & 整 & $=$ & & † & \\
\hline & 當 & 站 & & 资 & & 䇣 & & $1=$ & & 9 & 盟 & 5 & & 漓 & 文 & $=$ & 偖 & 》 & & 3 & \\
\hline & 场 & $i$ & & 第 & & 今ิ & & 定 & & 迅 & 题 & $\vec{k}$ & & ह & 部 & $\frac{2}{2}$ & 9 & 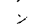 & & 成 & \\
\hline & 荡 & 全 & & で & & 医 & & 旅 & & 速 & $\varepsilon$ & る & & 光 & 省 & $4 x$ & 必 & 2 & & $1=$ & \\
\hline
\end{tabular}


堀江・山根：「医学洋書総合目録」の誕生一ユニオン・カタログ小史一(1) 349

なったのである。昭和 25 年度には約 3 力年の継続費の 当年度分として 75 万円が割当てられている。

昭和 18 年第 15 回総会に端を発した「Union Catalogue」は，編集および財政面で軌道に乗ることになる のである。

かくして、「UnionCatalogue」は実務者(司書), 館長そして 文部省の三者の協力の上にでき上がったといえる。と くに財政面その他で理解を示した文部省の馬場重徳の
尽力なしには「Union Catalogue」は実現できなかっ たといっても過言ではない。

昭和 24 年 9 月の第 1 巻から昭和 31 年 3 月の第 4 巻 まで実に 7 年の歳月をかけて「Union Catalogue of Foreign Books in the Libraries of Japanese Medical Schools」全 8 巻は完成したのである。（表 1 )

（次号へつづく）

表 1.「Union Catalogue」の発行順序

\begin{tabular}{|l|l|l|l|}
\hline 第 1 巻 $\mathrm{A}-\mathrm{Br}$ & 昭和 24 年 9 月 5 日 & 第 7 巻 $\mathrm{S}$ & 昭和 27 年 6 月 20 日 \\
第 5 巻 $\mathrm{M}-\mathrm{O}$ & 昭和 25 年 3 月 10 日 & 第 8 巻 $\mathrm{T}-\mathrm{Z}$ & 昭和 28 年 3 月 25 日 \\
第 2 巻 $\mathrm{Br}-\mathrm{Fo}_{\mathrm{O}}$ & 昭和 25 年 9 月 25 日 & 第 3 巻 $\mathrm{Fo}-\mathrm{Ho}$ & 昭和 29 年 10 月 10 日 \\
第 6 巻 $\mathrm{P}-\mathrm{R}$ & 昭和 26 年 9 月 25 日 & 第 4 巻 $\mathrm{Ho}-\mathrm{L}$ & 昭和 31 年 3 月 20 日 \\
\hline
\end{tabular}

\section{引用 文 献}

1）馬場重徳：医学困書館活動に関する断草. 医学困 書館, $3(1 \cdot 2), 137-140,1956$.

2）山川幸雄：日本医学図書館協会のあゆみ(1)。医学 図書館, $23(1) ： 9 \sim 17,1976$.

官立医科大学附属困書館協議会 - 医科大学附属図書館 協議会. 総会議事録第 1 回一第 20 回. 1927 1949. (議事録からの引用中, 原文はカタカ十のところはUら がなとした。また，字体は原則として新字を用いたが， 正字で表記したところもある)。

\section{参 考 文 献}

1) 三宅次吉：吾が協会生い立ちの憶い出. 医学図書 館, $4(4)$ : 235， 1957.

2 ）長尾公司：日本医学龱書館協会のあゆみ(2)一東 北地区医学図書館の活動：人とその背景—. 医 学図書館, $23(2): 55 \sim 59,1976$.

3 ）中里龍瑛：清川陸男さんの思出. 医学図書館, $2(5 \cdot 6): 116,1955$.

4 ) 中里龍瑛：白鷗漁史回想録. 医学図書館, $23(2)$ : $61 \sim 68,1976$.

5 ）中里龍瑛：日本医学図書館協会前向き推進の再認 識(1). 医学困書館, $27(2) ： 65 \sim 72,1980$.
6 ）中里龍瑛：日本医学困書館協会前向き推進の再認 識(2). 医学図書館, $27(3) ： 160 \sim 170,1970$.

7 ) 渡邊正亥：医科時代の思い出. 医学困書館, 4 (5) : 255 257, 1957.

8 ) 吉岡孝治郎：清川陸男さんの思い出. 医学図書館, $2(5 \cdot 6): 116,1955$.

9 ) 吉岡孝治郎：医科大学附属図書館協議会の思い出. 医学図書館, 4(4)：236, 1957.

\section{謝辞}

写真は, 当館の梅枝軍二氏から帱受した。梅枝軍二 氏の添之書きには次のように記してある。「この写真 は, 前橋医専(前橋医大) に勤女て間毛ない昭和 $22 \sim 23$ 年頃, 当時校長 (学長)だった西成甫先生から『この写 真は君が持っていた方が.......』といってもらったもの (梅枝)」

この写真の御名前の確認には,梅枝軍二氏をはじめ, 渡邊正亥氏および中里龍瑛氏，山川幸雄氏，長尾公司 氏の各名誉顧問のお手を煩わせた。

また，第 1 回からの総会議事録は中央事務局および 東京慈恵会医科大学附属四書館から拝借した。順天堂 大学困書館の横田隆之氏にもお世話になった。それぞ れの斿の゙厚意に心より御礼申し上げます。 


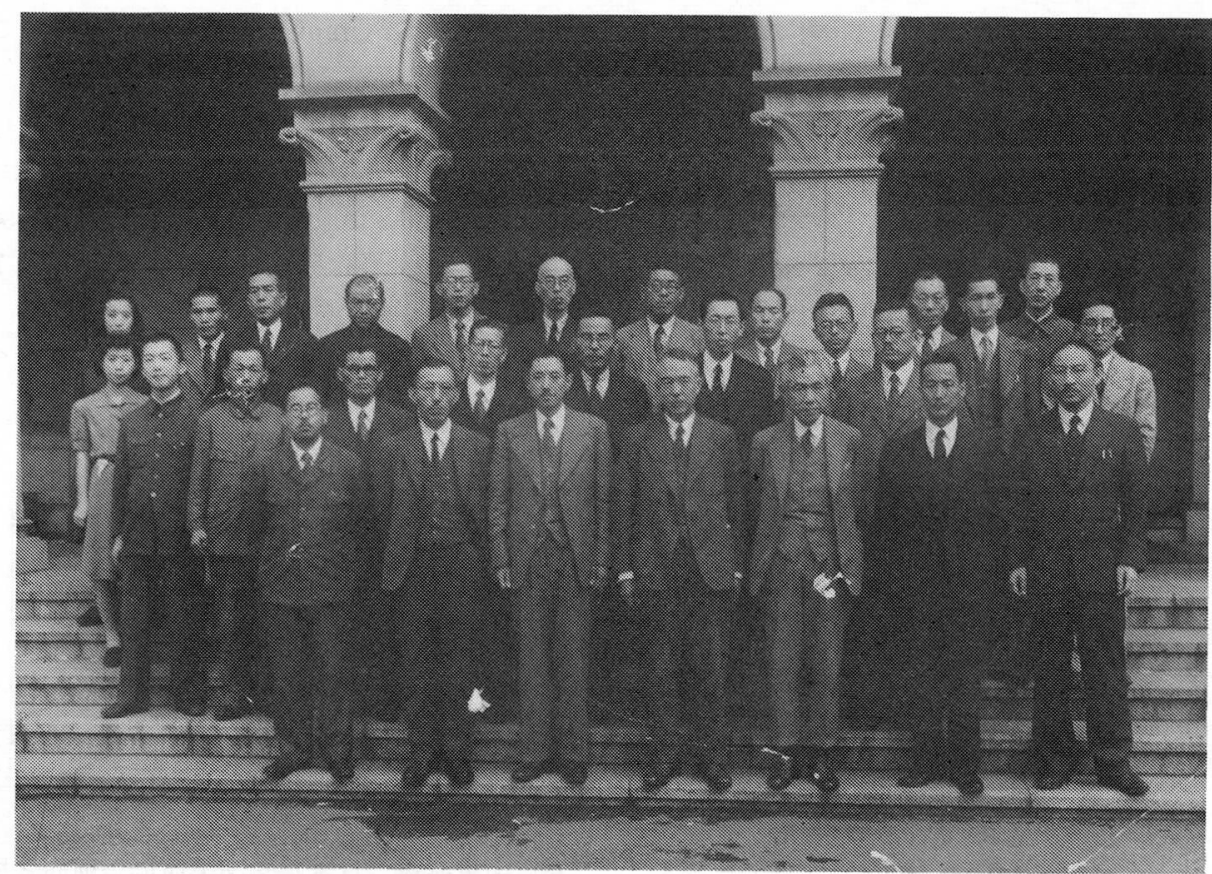

写真. 第 15 回医科大学附属図書館協議会(東大, 昭和 18 年)

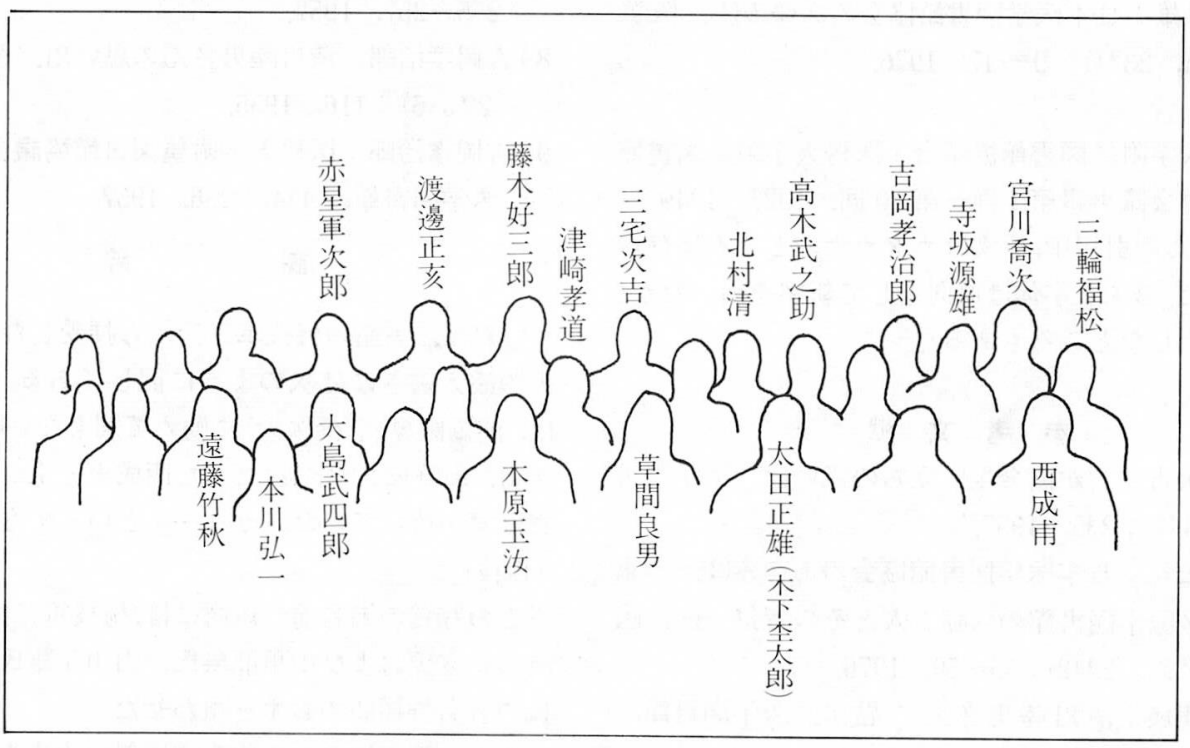


付録. ユニオン・カタログ略年表(1)

\begin{tabular}{|c|c|c|c|c|}
\hline & 総会回 & 当番館 & 議 & 決議内容・人物・その他 \\
\hline 昭和11年. & 第10回 & 熊本 & 「協議会として共同図書目録編纂の件」(阙は) & 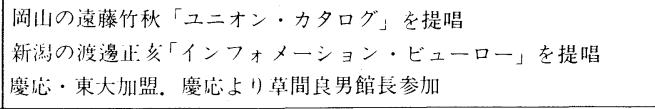 \\
\hline 昭和12年 & 第11回 & 新港 & $\begin{array}{l}\text { 「本会内にインフォメーション・ビューロー(Informa- } \\
\text { tion Bureau)の如きものを設け加入館に於ける新購入図 } \\
\text { 書を, 何等かの形式にて, 月一回同局に送附報告するの } \\
\text { 件」(名大) }\end{array}$ & 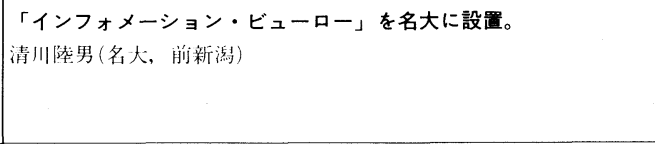 \\
\hline 昭和 13 年 & 第12[回 & 阙II & $\begin{array}{l}\text { 「インフォメーション・ビューローへの報告に，ある制 } \\
\text { 限を附しては如何」(限大) }\end{array}$ & 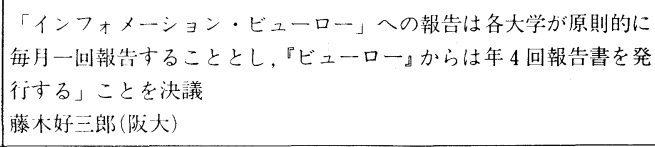 \\
\hline 昭和14年 & 第13[回 & 慶岕: & $\begin{array}{l}\text { 「現在名古屋帝国大学附偊図書館内に設置してある『イ } \\
\text { ンフォメーション・ビューロー』強化に就て」(阔川」) }\end{array}$ & 遠藤竹秋 (烊山) \\
\hline 昭和15年 & 第14回 & 下葉 & 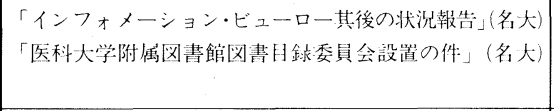 & $\begin{array}{l}\text { 「医科大学附偊図書館図書目録委員会」準備委員会の設置。 } \\
\text { 委員は清川陸男(名大)・渡邉正亥(新潟)・北村清(千葉) }\end{array}$ \\
\hline 昭和 18 年 & 第15回 & 東大 & 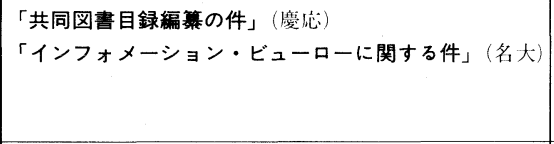 & $\begin{array}{l}\text { 草間良男・高林武之助(慶応)，太田正雄(木下李太郎) 東大当番館長 } \\
\text { 大島武四郎(名大)，西成甫 (東大教授)医学部長代理 } \\
\text { 名大「インフォメ一ション・ビューロ一」と慶応提唱による「医科 } \\
\text { 大学綜合医書目録」の } 2 \text { つの流れができる。 }\end{array}$ \\
\hline $\begin{array}{c}\text { 昭和 } 21 \text { 年 } \\
(6 \text { 月 })\end{array}$ & 第16回] & 京俯 & 「共同目録作業促進の件」(東大・東北) & $\begin{array}{l}\text { 戦後初の㓦書だけによる総会。東大に中央事務局を設置。 } \\
\text { 三輪福松・中里龍瑛(東大), 吉岡孝治郎(東北) }\end{array}$ \\
\hline $\begin{array}{c}\text { 昭和 } 21 \text { 年 } \\
\text { (10月) }\end{array}$ & 第17[回] & 金汱 & 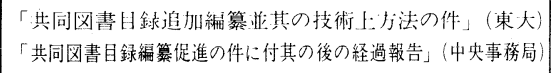 & $\begin{array}{l}\text { 三輪福松 (東大), 文部省より馬場重德参加. 新潟より赤崎兼義館長 } \\
\text { 参加 }\end{array}$ \\
\hline 昭和 22 年 & 第18[回] & 東北 & $\begin{array}{l}\text { 「インフォメーション・ビューローは現在自然消減の形 } \\
\text { ですが, 今後如何に処置しますか」(名大) } \\
\text { 「共同目銥出版促進の件」(慶伈) } \\
\text { 「和書総合目錄の計丒に就いて(熊本) }\end{array}$ & 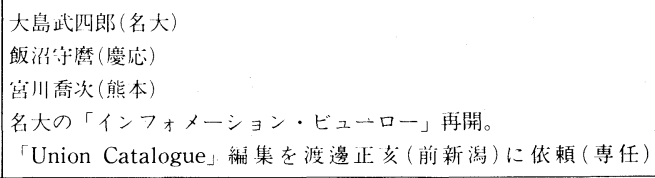 \\
\hline 昭和 23 年 & 第19回 & 阫大 & 「医科大学綜合目録印刷促進の件」(新潟) & 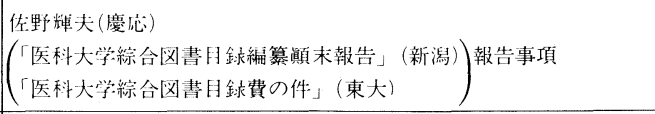 \\
\hline 昭和 24 年 & 第20[回 & 名大 & $\begin{array}{l}\text { 「総合目錄出版援助老依頼のため文部大妵に送る決議文 } \\
\text { について」(失䇨老打合せ会議題) }\end{array}$ & 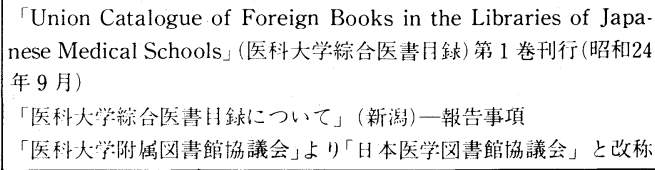 \\
\hline
\end{tabular}

